\title{
Evaluation of corn grain quality as produced by farmers at Marantao, Lanao del sur
}

\author{
Aldrees Ansary Baraocor Guro, MS \\ College of Agriculture, Mindanao State University, Main Campus - Marawi City
}

\begin{abstract}
The Study was conducted purposely to evaluate the farmers' practices, post-harvest handling and income of Corn farmers in Marantao, Lanao del Sur. The study was administered in the Municipality of Marantao, Lanao del Sur. Samples were selected through random sampling. The study used descriptive quantitative and qualitative method. The data were gathered mainly through the use of questionnaires in order to identify the profile of the respondents, practices and knowledge. This study will be conducted to find out the socio-economic profile of the respondent and if there are significant relationship between grain quality and possible factors like Farmers Income in Pesos, Price per kilogram, Hectarage, Variety, Drying Method, Farming Method, Shelling Method, Crop Days to Maturity, Maturity Indices, Age of the Respondent, Gender of Respondent, Civil Status, Educational Attainment, Years in Farming, Frequency of Wedding. Majority (92\%) are married, 6\% single and $2 \%$ widow, Male farmers are (90\%) while female farmers are (10\%). Majority of the farmer respondents are more belonging to age bracket of 31-34. Majority of the farmer respondents attained elementary education (56\%), 22\% attained high school, 14\% in college and 8\% illiterate. Majority (96\%) of the respondents owned the land they till. The farmer respondents are majority (94\%) using the traditional method only (6\%) using scientific farming. Most of the respondents (52\%) have 1-5 years of farming experience, (32\%) had 15 years of experience in farming, while 10\% of them were doing same thing for 25 years. And majority $98 \%$ of farming practices used by the respondents used native corn variety and practiced the manual method of harvesting $60 \%$ of which is picked before dehusking while $40 \%$ dehusk the corn before picking. All respondents practiced the mechanical method of shelling. 60\% of which are dried their corn before shelling and 40\% shell the corn before drying.
\end{abstract}

Keywords: evaluation, corn grain quality, farmers,

\section{Background of the Study}

Corn (Zea mays L., also known as maize) is a member of a grass family Gramineae and classified as an annual crop. It is the largest of all the cereals and its height would reach as tall as 15 feet. The stem also known as the cornstalk is jointed and looks like bamboo. It contains both male and female flowers, which are at the top of the stalk, and its female flowers in which the male flowers are borne in the tassel that is at the top of the stalk, and is female flowers are clustered at the joint of the stalk.

In the Philippines almost three million hectares of land devoted to the cultivation of corn annually, but current production is not enough to meet the local needs due to low yield. Corn importation of the Philippines has been in the increasing trend to supply the needs of the Filipinos. The volume of corn imports contracted by 
41.05 percent and settled at 0.48 million metric tons in 2017. Payment for corn imports at $\mathrm{PhP} 6.51$ billion declined by 35.41 percent and this comprised a reduced share of 1.10 percent in 2017 (Agricultural Exports and Imports, AIS Report 2018-4).

Corn production in the Philippines is also affected by climate change and soil degradation. Perera, K.T.G.K, Weerasinghe, T.K (2014), said that bulk density and microbial biomass of the soil seem to be the best indicators to determine the soil quality reduction and soil deterioration with maize monoculture cultivation. Their study findings revealed that the soils in maize plantation have deviated from the natural forest soil conditions. This is due to microbial biomass declining and land degradation due to some other crops planted. Multiple research conducted the same topics revealed that microbial biomass varies in accordance of various crop growing (Wander, (1999)[39] \& Weerasinghe(2012). Furthermore, Jagadamma(2009), reported that the organic matter content of soil under Corn could be reduced over the time due to erosion and the absence of underground growth. Ortega, R.A. and Oscar A. Santibanez, O.A. (2007), determined the management zones in corn. Researches on soil quality considering the effect of Zea mays on soil was conducted and their findings revealed that monoculture maize based systems in the world have indicated that bulk density and moisture content were changed.

One reason behind the demand of corn is that it used for many purposes like staple food to some Filipinos. When processed it serves as fine feeds to livestock. Some small farmers engaged corn production aa their cash crop in which after seventy-five days of planting, the crop has its yield in which the corn ear at green mature form can already be disposed to market, thus giving income to small farmers in short growing period of time. On the other hand, new markets have developed corn by-products, including the manufactures of fiber board panels, nylon products, furfural (used in plastics and solvents) and ethanol as renewable vehicular fuel. In fact, more than 3,500 different uses of corn products have been found.

P.W.Wambugu, ${ }^{1}$ P.W.Mathenge, ${ }^{2}$ E. O. Auma, ${ }^{3}$ andH. A.vanRheenen ${ }^{4}$ (2012) research findings on their study about Constraints to On-FarmMaize (Zeamays L.) Seed Production in Western Kenya: Plant Growth and Yield showed that fertilizer application led to an increase of agricultural yields and at the same time increase the seed vigor and viability. Research study of M. C. Shiluli, C. N. Macharia, and A. W. Kamau (2003) found out that the local varieties produced without fertilizer had the highest benefit: cost ratio. This implies that fertilizer application affects the corn product yields and seed or grain quality. Moreover, the risk of declining seed quality and yield indicate the local seeds are not always optimal (P. W. Wambugu, 2012).

Since corn plays an important economic role in the country, it motivates local corn growers to engage corn productions in all cropping season provided farm environment favors its growth. The production is feasible to environment in which the temperatures range from 10 degrees Celsius to 25 degrees Celsius. Due to high economic return and its wide range of adaptability from region to region, farmers in Lanao del Sur, particularly in the Municipality of Marantao, are encouraged to venture into corn production.

Corn production in Marantao has its potential. However, corn farmers could not attain the highest possible return due to low price of corn grains; price of farm produced would vary as to its quality. Therefore, the study was conducted to determine the different prices of corn grains in terms of its quality and the other factors that contribute to the prices of the corn grains. 


\section{Statement of the Problem}

The farmers' income is one of the motivating factors for sustainable corn production. In some areas of Mindanao, particularly the province of Bukidnon, farmers are continuously producing corn because of its market demand. However, one of the contributing factors for good price of corn grains is quality. The quality of corn grains is affected by the technology and associated factors during planting and post-harvesting periods.

The quality of corn grains locally produced by farmers in different Barangay's in the Municipality of Marantao are directly influenced by some factors practiced during planting and post-harvest handling of corn grains. Specifically, it sought to answer the following:

1. Respondents profile such as:
a. Civil Status
b. Gender; and
c. Educational Attainment?

2. What is the method of farming practiced by the farmers of the Municipality of Marantao?

3. Is there any significant relationship between grain quality and the possible factors enumerated as follows;
a. Farmers Income (in Php)?
b. Price per Kilogram?
c. Hectarage?
d. Variety?
e. Farming Method?
f.Shelling Method?
g. Crop Days to Maturity?
h. Maturity Indices?
i. Age of the Respondent?
j.Gender of the Respondent?
k. Civil Status?
1.Educational Attainment?
m. Years in Farming?
n. Frequency of Weeding?

\section{Theoretical Framework}

The corn grain quality differs from one farmer to another depending on the practices employed by farmers during harvesting like corn ear picking, shelling, drying and storing. This study was conducted to assess the method of harvesting and drying of corn grains in five Barangays in the Municipality of Marantao. In harvesting, the most practical and reliable ways of determining the maturity of ear for seed are knowing the age of maturity and determining the moisture content. Corn seed has about 27 percent moisture at maturity. The moisture content is determined by deducing the dry weight (weight after drying) from the fresh weight (weight just after harvesting), then dividing the difference by the dry weight and multiplying the quotient by 100 .

In determining the moisture content before harvesting, sample ears must be taken from the marked plants. 
Moisture content of corn grain can be easily determined with the moisture meter. In addition, the method of harvesting also has requirement-harvest the moisture-marked ears ahead of the rest. For halayhay, cut the com stalk 5 centimeters below and 15 centimeters above the ear; the stalk will be used for drying later and for shelling purpose, remove only the ears.

In drying any method can be used as long as it suits the means for storage.one methods are halayhay. This method is different from other methods because the unhusked corn ears are hung up in rows starting below. Both sides of the arrangement are filled up in this manner. To make sure that the ears do not retain water, arrange them in such a way that the passage of weevils into the kernels. Some farmers practice drying in that corn kernels are still attached to the cob. Other farmers practiced shelling before drying if the moisture content is not too high.

Air temperature for drying corn seed ranges from 90 to $100^{\circ} \mathrm{F}$. The maximum air temperature is $115^{\circ} \mathrm{F}$. High temperature may affect the viability of corn seeds specially if drying starts when the grain contains a lot of water. Avoid abrupt drying.

One of the requirements for drying the seeds is that it must be slowly until the moisture content reaches up to 12 to 14 percent. This moisture content keeps the seeds in prolonged storage from rotting. If a drier is used, the temperature should not be above $40^{\circ} \mathrm{C}$ or $104^{\circ} \mathrm{F}$. if the seeds are dried under the sun, they are not spread directly on asphalt or cement road. The temperature may rise above the right point and kill the embryo of the seed. To prevent this possibility, put matting under the seeds.

\section{Conceptual Framework}

Harvesting method is one of the requirements to produce quality grains it must be harvested at the proper time. The time to harvest will depend on the purpose, either for food, for feeding animals, or sending it to market. Each purpose has its own specific time for harvest.

Corn ears will be harvested when mature and if they are to be used for grain. Dryness of leaves husks and glazed kernels are signs of maturity. Accordingly, corn matures 7 to 8 weeks after flowing. At this point the grains are at their maximum dry weight. The moisture content is about 35 to 40 percent. It is a requirement to know the length of maturity of the crop. It will guide in harvesting corn on time. It is emphasized that mature grains keep better and longer in storage that immature ones. However, corn is not like rice, which is much affected by late harvesting. Corn does not shake out. Can be left on the stalk until it is quite dry. The moisture content in the grain can be reduced to 20-25 percent.

They are advantages in early harvesting. One is it minimize excessive loss of seed in the field, if mechanical picker is used. It reduces risks of delay in harvesting due to rainy weather. It prevents further development of ear-rot fungi. It stops insect damage. Minimize severe husking losses when picker is used. Harvested ear should be dried right away. Dry before and after shelling. For safe and long storage dry corn to 13 to 14 percent moisture. He harvested crop is still of little value until it is marketed. Decide whether you market the crop of hold it for some time. If you decide for a better price, then you have to store your corn properly. Proper moisture for storage should be below the moisture content at harvest. One of the important things to 
know for early harvesting is it will reduce losses from storage, attacks of pests and disease and natural shuttering it permits long-time storage, maintains the viability of seeds and permits sell better-quality products.

\section{Independent Variables}

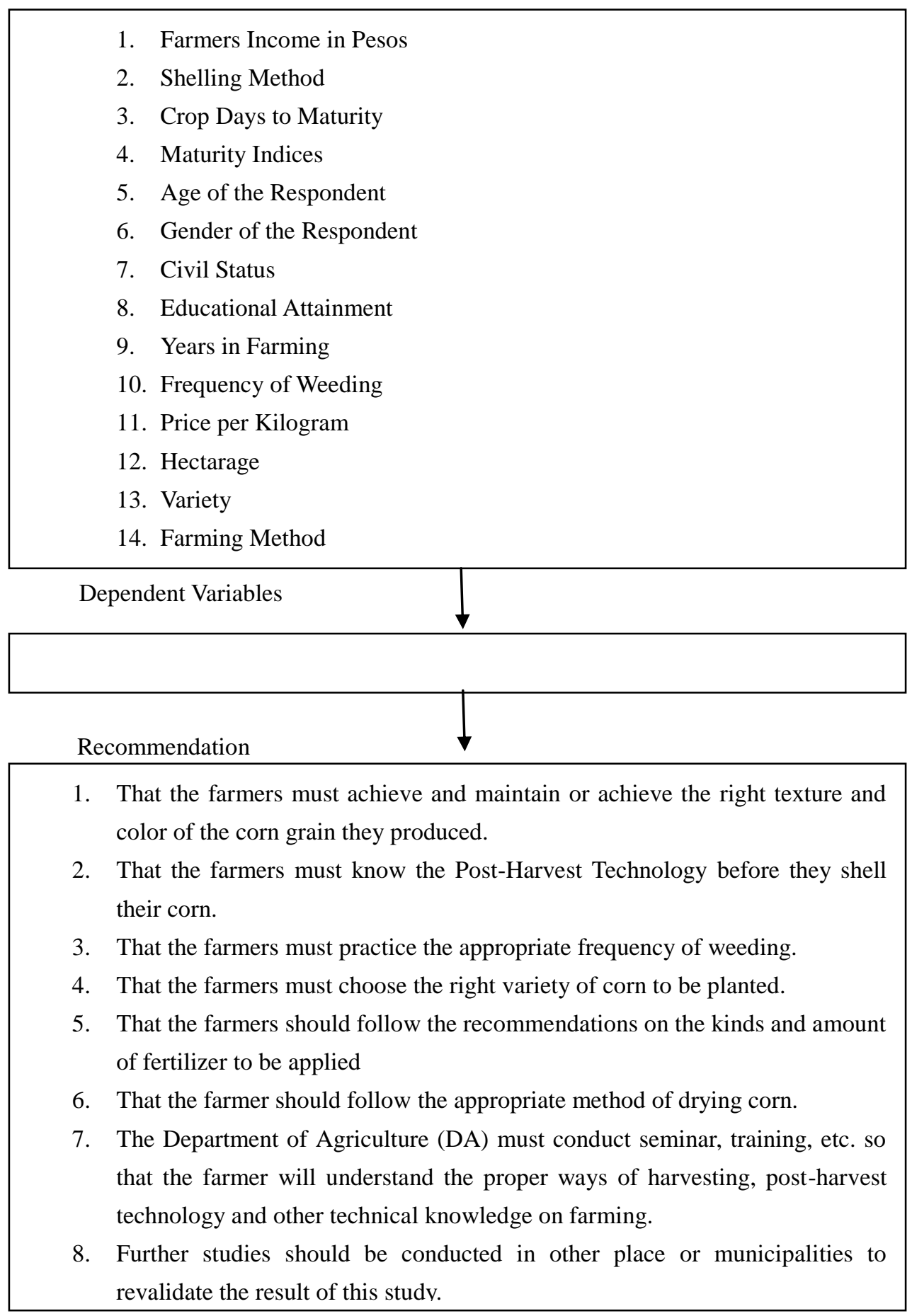

Figure 1. Paradigm of the Study

\section{Significance of the Study}

Corn production can be an avenue for increasing income of farmers because its cultural management and 
practices are simple and can be easily adopted. This crop is a promising alternative in areas devoted to rice but not certain of receiving adequate supply of water throughout the growing period because corn water requirement or the water consumptive used is less compared to rice. As to its production, farmers can produce more yield, but the net income could not supply the family's need due to low price, which is affected by the quality of the grains. To obtain highest possible return for corn production, corn growers must have knowledge on postharvest handling. The important factors affecting grain quality must be taken into consideration, thus this study is conducted.

\section{Scope and Limitation of the Study}

The study was conducted in the Municipality of Marantao. It is limited corn farmers in different barangays of the Municipality. In particular, this study involved five barangays with 10 farmers each barangay. The research work is limited to the study and evaluates the quality of corn grains being produced by the farmers and the problems they encountered in producing low quality grains.

\section{Research Design}

This study uses the descriptive -correlation design with the aim to know the profile of the farmers and the farming practices they employ in corn production and to determine the potential relationship between certain factors and grain quality.

\section{Locale of the Study}

The study was conducted in Marantao, Lanao del Sur. Marantao is the first municipality in the southwest of Marawi City. It is almost 7 kilometers away from the city proper. It is a third-class municipality in the province of Lanao del Sur, Philippines with a total population of 24,647 in 3,598 households.

Marantao is politically subdivided into 34 barangays. These are Bacayawan, Cawayan Bacolod, Bacong, Camalig Bandara Ingud, Camalig Bubong, Camalig (Pob.), Inudaran Linuk, Lubo, Inudaran Lumbac, Mantapoli, Matampay, Maul, Nataron, Pagalongan Bacayawan, Patamais, Poona Marantao, Punud Proper, Tacub, Maul Ilian, Palao, Banga-Pantar, Batal-Punud, Bubong Malanding (Bubong), Ilian, Inudaran Loway, Maul Lumbaca Ingud, Poblacion, and Tuka Kialdan.

Cultural zoning of the royal houses relate that is part of Mala-a-Bayabao royal houses. Although some part of it is not hilly, most portions are plain. It is considered a plain municipality along the circumferential shores of the Lake Lanao. It is also the emerging generating power source of the National Power Corporation, which cater to the power-light supply of many provinces in Mindanao.

It has a generally favorable climate condition. It is free from strong weather disturbances. Vast trees and forest resources with the line crest of the range of mountains nearby make the town uniformly cool and refreshing. Dry seasons occur during February to May, but moderate to heavy rainfalls during June to December of every year.

Soil is potential for production of major crops like rice, corn, coffee, banana, sweet, potato, vegetable and others. The soil is mostly plain in with high fertility noted to suit several kinds of fruit trees even bamboos trees, falcate and ipil-ipil trees.

Large animals like cattle and carabao are used as farm work animal. Goats are raised as additional family income. Chicken are raised on a limited commercial scale for local consumption despite environment access of poultry raising. Muslim Meranaws inhabit the municipality. Most inhabitants are common farmers, anglers, 
handicrafts maker, employees and businesspersons.

\section{Research Instrument}

The study used structured questionnaire developed and validated by the researcher. It has three parts, namely, Part I (Respondent Profile), Part II (Farming Practices), and Part III (Kinds of Inputs and Cost).

\section{Sampling Method}

This study used probability random sampling method. Five (5) barangays were randomly selected using indices of random numbers, and ten (10) farmers were randomly chosen in each barangay as respondent.

\section{Statistical Treatment}

All information that had been obtained from questionnaire was tabulated. In the analysis and presentation of the collected data, the Pearson correlation analysis was utilized. The mean, standard deviation and random sampling of respondent are computed and the non-Numerical data are converted to numerical indices in order to get the right result.

\section{Summary of Findings}

The study was conducted at Barangay Campong Inudaran, Linuk Cawayan, Camalig, Ilian Maul, Bacong with actual respondents of (50) fifty local farmers to find out the socioeconomic profile of the respondents, their farming practices, the kinds of input and cost, and the relationship of the aforementioned variables to grain quality. Based on the analysis of data the findings are summarized as follows:

1. Their profile information revealed that majority were married, male, and were between 31 to 34 years old. Majority of the farmers-respondents attained elementary education (56\%), 22\% attained high school, $14 \%$ in college, and $8 \%$ illiterate. Majority (96\%) of the respondents owned the land they till.

2. Majority (94\%) as well as using the traditional method and only (6\%) used scientific farming.

3. Most of the respondents (52\%) have 1-5 years of farming experience; (32\%) had 15 years of experience in farming, while (10\%) of them were doing same thing for 25 years. In addition, majority (98\%) of farming practices used by the respondents are inorganic.

4. Most of the respondents used the corn variety and practiced the manual method of harvesting, $60 \%$ of which is picked before dehusking while $40 \%$ dehusk the corn before picking.

5. All respondents practice the mechanical method of shelling; $60 \%$ of which are dried before shelling and $40 \%$ shell the corn before drying.

\section{Conclusion}

Based on the results of the study, the following conclusions were drawn, to wit:

1. There is a significant relationship between grain quality and unit price in pesos $/ \mathrm{kg}$ at 0.01 level significance.

2. There is a significant relationship between grain quality and shelling method at 0.05 level of significance

3. There is a significant relationship between grain quality and the number of weeding at 0.01 level significance.

4. There is a weak relationship between grain quality and farmers' income in pesos at $r=-0.129$. 
5. There is a weak relationship between grain quality and hectarage at $r=-.146$.

6. There is a weak relationship between grain quality and variety used at $r=-.235$.

7. There is a weak relationship between grain quality and farming method at $r=-.235$

8. There is a weak relationship between grain quality and crop maturity in days at $\mathrm{r}=-.252$.

9. There is a weak relationship between grain quality and maturity index at $\mathrm{r}=-.069$.

10. There is a weak relationship between grain quality and age of respondents at $r=-.256$.

11. There is a weak relationship between grain quality and gender of respondents at $r=-.041$.

12. There is a weak relationship between grain quality and civil status of respondents at $r=-.082$.

13. There is a weak relationship between grain quality and educational attainment of the respondents at $\mathrm{r}=-.123$.

14. There is a weak relationship between grain quality and years of farming of the respondents at $r=-.144$.

\section{Recommendations}

Based on the above-mentioned conclusions, the following recommendations are presented

1. That the farmers must achieve and maintain or achieve the right texture and color of the corn grain they produced.

2. That the farmers must know the Post-Harvest Technology before they shell their corn.

3. That the farmers must practice the appropriate frequency of weeding.

4. That the farmers must choose the right variety of corn to be planted.

5. That the farmers should follow the recommendations on the kinds and amount of fertilizer to be applied

6. That the farmer should follow the appropriate method of drying corn.

7. The Department of Agriculture (DA) must conduct seminar, training, etc. so that the farmer will understand the proper ways of harvesting, post-harvest technology and other technical knowledge on farming.

8. Further studies should be conducted in other place or municipalities to revalidate the result of this study.

\section{References}

[1] AIS (2018). Agricultural Exports and Imports. Report No. 2018-4 Philippine Statistics Authority ISSN 2012-0435.

[2] Jagadamma, S, Lal, R and Rimal, B.K. (2009) Effects of topsoil depth and soil amendments on corn yield and properties of two Alfisols in central Ohio, Journal of Soil and Water Conservation, Vol. 64 no.1, pp: 70-80

[3] M. C. Shiluli, C. N. Macharia, and A. W. Kamau (2003). "Economic analysis of maize yield response to nitrogen and phosphorus in the sub-humid zones of Western Kenya,” African Crop Science Journal, vol. 11, no. 3, pp. 181-187, 2003.

[4] Perera, K.T.G.K, Weerasinghe, T.K (2014). A Study on the Impacts of Corn cultivation (A Study on the Impacts of Corn cultivation ( Zea mays (1) Family - Poaceae) on the properties of Soil. International Journal of Scientific and Research Publications, Volume 4, Issue 7, July 20141 ISSN 2250-3153 www.ijsrp.org

[5] P.W.Wambugu, ${ }^{1}$ P.W.Mathenge, ${ }^{2}$ E. O. Auma, ${ }^{3}$ andH. A. vanRheenen ${ }^{4}$ (2012). Constraints to On-FarmMaize (Zeamays L.) Seed Production in Western Kenya: Plant Growth and Yield. International Scholarly Research Network, ISRN Agronomy Volume 2012, Article ID 153412, 7 pages, doi:10.5402/2012/153412 
[6] P. W. Wambugu, On-farm Seed Production, Storage and Preservation of Selected Local Maize (Zea mays L.) Germplasm inWestern Kenya: The Case of Siaya and Busia Districts[Master of Philosophy Thesis], Moi University, 2006.

[7] Rodrigo A. Ortega, Oscar A. Santibanez (2007) Determination of management zones in corn (Zea mays L.) based on soil fertility, Science Direct, Vol.58(I), pp:49-59

[8] Sherry R. Whitt, Larissa M. Wilson, Maud, Tenaillon, Brandon S. Gaut, and Edward S. Buckler (2002) Genetic diversity \& selection in the maize starch pathway, Proceedings of the National Academy of Sciences U.S.A.; 99(20): 12959-12962

[9] Weerasinghe, T.K (2012) Impacts of land use changes to a dry evergreen natural forest through some microbiological properties, International journal of Research in bio sciences, Vol. 1, pp: 20- 26. 